Поярков С.Ю.

\title{
ПРОБЛЕМЫ РЕАЛИЗАЦИЯ КОНЦЕПЦИИ КОНСТИТУЦИОНАЛИЗМА НА НАДГОСУДАРСТВЕННОМ УРОВНЕ
}

\begin{abstract}
Аннотация: Предметом настоящего исследования является процесс и условия становления конститущионализма на надгосударственном уровне общественных отномений. Потребность осмысления процесса становления конституичиоализма на надгосударственном уровне обусловлена тем, что процесс конституичионного развития во многом определяется процессами глобализации и денационализации в условиях, когда государство остается основным субъектом международных отношений. Учитывая, что конституиионализм выступает как особая система, определяющая форму организации и динамику политиковластного взаимодействия государства и гражданского общества, на надгосударственном уровне происходит дублирование механизма становления конституиионализма. Что порождает проблемы, связанные с легитимностью власти, суверенитетом государства и правами человека на уровне государства и в глобальном масштабе. Методологией настоящего исследования послужсил системный подход как совокупность методов и способов многомерного представления конституичонализма как феномена глобализаици Исследованием определено, что проблемы становления конституционализма на надгосударственном уровне обусловлены отсутствием иелостных идеологических оснований политико-правового объединения автономных, самостоятельных образований, при недостаточных условиях формирования институтов конституционализма в глобальном масштабеВ современном обществе становление надгосударственного конституционализма обусловлено, во-первых, необходимостью институционального упорядочивания процессов развития существующей системы международных отношений с целью создания условий, когда более эффективная политическая активность становится катализатором развития общества, во-вторых, потребностью ограничения действия существующих субъектов политической власти и формированием новых институтов при условии сохранения сферы автономии для государства или других субъектов, и, в-третьих, для дополнения и усиления внутренних конституционных гарантий.
\end{abstract}

Review: The object of this study is the process and conditions for the formation of constitutionalism at the supranational level of social relations. The need to understand the process of formation of constitutionalism at the supranational level is due to the fact that the process of constitutional development is to a great extent defined by the processes of globalization and denationalization in the conditions when the state remain the main subject of international relations. Taking into account that constitutionalism is a special system defining the form of organization and dynamics of the political force in the interactions between state and civil society, the supranational level duplicates this mechanism of constitutionalism formation. It causes problems regarding legitimacy of power, sovereignty of the state and human rights at the national and global levels. The methodology of this study involves systemic approach as a combination of methods and means of multidimensional idea of constitutionalism as a globalization phenomenon. The study defines that the problems of formation of constitutionalism at the supranational level are caused by the absence of comprehensive ideological fundamentals for the political and legal associations of autonomous independent formations due to the insufficient formation of constitutionalism structures at the global scale. In the modern society the formation of supranational constitutionalism is caused by, firstly, the need for the institutional systematization of the development processes in the existing system of international relations in order to form the situation when efficient political activity catalyzes social change. Secondly, it is due to the need to limit the activities of the existing subjects of political power 
and to form novel institutions while preserving the sphere of autonomy for states or other subjects. Thirdly, it is necessary in order to complement and strengthen internal constitutional guarantees.

Ключевые слова: Конституционализм, политическая система, политическая власть, государство, глобализачия, конституционный порядок, системный подход, мировой порядок, целостность, гражданское общество.

Keywords: Constitutionalism, political system, political power, state, globalization, constitutional order, systemic approach, global order, integrity, civil society.

$\Pi$ отребность осмысления процесса становления конституционализма на надгосударственном уровне обусловлена тем, что процесс конституционного развития во многом определяется процессами глобализации и денационализации в условиях, когда государство остается основным субъектом международных отношений. В этой связи, одной из ключевых проблем становления конституционализма на надгосударственном уровне является то, что в современной политической традиции идея равенства государств как самостоятельных правовых субъектов является доминирующей, несмотря на различный характер государств с точки зрения их территориального присутствия, численности населения, религиозного и культурного бытия, политической системы и других факторов. Как утверждает У. Пру, в конституционном глобальном обществе проверенный временем принцип равенства, по своей сути, уже не связан с существующим горизонтальная или неорганизованный сообществом государств и должен быть переосмыслен и адаптирован к условиям современной международной взаимозависимости ${ }^{1}$. Но подобный отход от принципа равенства может предполагать необходимость единого надгосударственного носителя политической власти - если мы говорим о становлении конституционализма.

Особую значимость в сфере конституционного развития процессы глобализации приобрели в 90-х годах прошлого века и были связаны, вопервых, с окончанием «холодной войны» и становлением единых политических идей, усилению международного сообщества как единого образования с общими ценностями и, возможно, единых конституционных рамок. Во-вторых, усиление институционализации международной политики, проявившееся как в усилении Организации Объ-

${ }^{1}$ Preu U. Equality of States. Its Meaning in a Constitutionalized Global Order $\backslash$ Hertie School of Governance - working papers, No. 15, April 2008. единенных Наций (ООН), Всемирного банка, так и в появлении новых организаций - Европейского союза, Всемирной торговой организации (ВТО), Всемирной организации здравоохранения (ВО3), Международной организации труда (МОТ), реализующих в своей деятельности функции, ранее выполнявшиеся исключительно государствами. И, в-третьих, процессы глобализации в экономике стимулировали рост отношений между внутренней и международной политикой, предполагая новации в концептуализации модели межгосударственных взаимодействий.

Сама по себе идея «глобального конституционализма» (а так же «международного», «наднационального» и других видов) является достаточно новым явлением, серьезно изменившим характер глобального политического порядка. Но на сегодняшний день ясное понимание концепции глобального конституционализма отсутствует, несмотря на уже более 20 -летнюю историю научных исследований. Конституционализм в эпоху глобализации породил дилемму между национальным и глобальным уровнями, где первый определяет конституционализм на уровне государства как единственный источник законной политической власти, а второй - доминирование глобального подхода в преодолении отчуждения и ограничения государственного конституционализма.

Критическое рассмотрение исследований подтверждает, что современное видение глобального конституционализма преимущественно формируется на основе центральных принципов такой формы правления как либеральная демократия, которая основывается на идеологии политического либерализма. Либерализм в этом смысле характеризуется двумя элементами формальной автономии и абстрактного равенства; демократия характеризуется народным представительством в общественно-политической сфере. Существующий в неолиберальной традиции подход к конституционализму рассматривает его как переход 


\section{Политика и общество 7 (115) • 2014}

от государственного устройства к глобальному через глобализацию общественных сил, в том числе и негосударственных субъектов с доминированием свободной торговли ${ }^{2}$, отходом от государственности и формированием квазиконституционных международных соглашений ${ }^{3}$ при снижении роли национальных конституций.

В основе подобных рассуждений лежит твердая уверенность в том, что либеральные демократические идеи способны определить не только конституционализм в национальных государствах, но и конституционализм на глобальном уровне. Проблему вызывает уже то, что эти идеи часто рассматриваются в качестве единственных доступных идей, что, естественно приводит к ограниченности в оценке происходящих процессов конституционализации и однобокому подходу к рационализации межгосударственных отношений.

Глобальный конституционализм, указывают Ф. Шоркопф и К. Уолтер ${ }^{4}$, отражает переход от «акторцентр» концепции международного права сфокусированного на регулировании отношений между суверенными государствами, к «субъект-центру» с пониманием международного права как регулирующего специфические области нормативного основания, таких как торговля, безопасность и окружающая среда, а также вопросы границы между международным правом и национальным конституционным правом. Так же, предпринимаются попытки применения концепции глобального конституционализма для социальных практик, ограничивающих политическое поведение и возрастания роли судебной власти (например, Д. Касс ${ }^{5}$ ). В свою очередь, А. Петерс $^{6}$ суть глобального конституционализма опре-

\footnotetext{
${ }^{2}$ Michael A. Globalization and Peremptory Norms in International Law: fromWestphalian to Global Constitutionalism? International Politics 2004. 41(3): P. 341-353.

${ }^{3}$ Stephen G. Constitutionalizing Inequality and the Clash of Globalizations. 59-60 International Studies Review 2002. (2): P. 47-65.

${ }^{4}$ Schorkopf F. Walter C. Elements of Constitutionalisation: Multilevel Structures of Human Rights Protection in General International and WTO-Law. German Law Journal 2003. 4(12): P.1359-1374.

${ }^{5}$ Cass D. Z. The Constitutionalization of the World Trade Organization. Legitimacy, Democracy, and Community in the International Trading System. Oxford: Oxford University Press. 2005.

${ }^{6}$ Peters A. Compensatory Constitutionalism: The Function and Potential of Fundamental International Norms and Structures. Leiden Journal of International Law 2006. 19(3): P.579-610.
}

деляет как условие компенсации существующей деконституционализации на государственном уровне. В развитие данного понимания она указывает на то, что глобальный конституционализм является научной и политической доктриной, которая идентифицируется сторонниками применения конституционных принципов в международной сфере в целях повышения эффективности и справедливости международного правового порядка ${ }^{7}$. Так же глобальный конституционализм определяется как явление замещающее политические пробелы, возникающие в результате различных преобразований, связанные с глобализацией и последующего деконституционализации «национальных правовых структур в условиях все более взаимозависимого мира» ${ }^{8}$.

В ряде исследований глобальный конституционализм концептуально затрагивает фундаментальную структуру и основные нормы международного порядка в целом (Э. де Вет 9 , Дж. Трачман $\left.{ }^{10}\right)$, во-первых, с упором на общие конституционные принципы, такие, как разделения властей, верховенства закона и, возможно, даже демократия, а во-вторых, приводя нормы международного права в большее соответствие с положениями конституционного права ${ }^{11}$.

Некоторые исследователи предполагают, что глобальная конституционализация представляет собой ступень к формированию системы международных отношений с учетом конституционных функций, источником которых являются национальные конституционные системы $^{12}$. В этом случае, консти-

${ }^{7}$ Peters A. \& Armingeon K. Introduction-Global Constitutionalism from an Interdisciplinary Perspective, 16 Ind. J. Global Legal Stud. 385 (2009)

${ }^{8}$ Peters A. Compensatory Constitutionalism: The Function and Potential of Fundamental International Norms and Structures (2006) 19 Leiden Journal of International Law 579 .

${ }^{9}$ De Wet E. The Emergence of International and Regional Value Systems as a Manifestation of the Emerging International Constitutional Order. “ Leiden Journal of International Law 2006. 19(3): P. 611-632.

${ }^{10}$ Trachtman J. P. The Constitutions of the WTO. " European Journal of International Law 2006. 17(3): P.623-646.

${ }^{11}$ Joerges Ch. nd Petersmann E.U.,eds. 2006. Constitutionalism, Multilevel Trade Governance and Social Regulation. Oxford: Hart Publishing.

${ }^{12}$ Klabbers J., Peters A. and Ulfstein G. The Constitutionalization of International Law (Oxford University Press, Oxford, 2009); Werner (n.16). 
туционализация, как процесс реализации конституционализма на международном уровне, выступает как формализованный и объективный политикоправовой механизм с наличием соответствующих им механизмов политической власти, которые по аналогии с конституционными требованиями, установленными в национальных государствах, предполагают существование обязательств, ответственности при условии верховенства права. Это порождает стремление глобального конституционализма выступить как процесс институционализации международного порядка. Как отмечает Г. Тубнер, такой процесс предполагает появление, создание и отождествление двух самостоятельных элементов, которые регулируют международную политику: институциональные и организационные принципы для межгосударственных отношений и основных положений о правах человека для физических лиц ${ }^{13}$.

В отличие от формального понимания международных отношений, в основе которых лежит доктрина государственного суверенитета и была в основном посвящена иммунитету государств, их дипломатических представителей, и их собственности, появление международных фундаментальных прав является достаточно новым явлением. В основе этого может лежать признание личности в качестве конечной доминанты современной международной политики по признанию основных прав. Соответственно, признание прав человека является синонимом признания личности не только как самостоятельного субъекта международной политики, но и детерминантой институционализации возникающих отношений на новом уровне - конституционном. Это означает, что современное международное право уже не исключительно связано с регулированием межгосударственных отношений, но и с отношениями между индивидом и его политико-правовым состоянием ${ }^{14}$. Таким образом, идея глобального конституционализма должна рассматриваться как связка двух специфичную наборов правил, которые развиваются с течением време-

${ }^{13}$ Teubner G. Societal Constitutionalism: Alternatives to StateCentred Constitutional Theory? In Transnational Governance and Constitutionalism: International Studies in the Theory of Private Law, ed. Christian Joerges, Inger-Johanne Sand and Gunther Teubner. Oxford: Hart Publishing. 2004. P. 3-28.

${ }^{14}$ Lauterpacht $H$. International Law and Human Rights. London: Stevens. 1950. P. 61-67 ни: формальная нормы, которые содержат в первую очередь принцип верховенства права, а также основные нормы, сущность которых состоит в гарантии основных прав физическим лицам. ${ }^{15}$

В ряде исследований указывается на то, что процесс развития международного права и становление новых международных институтов приводит к более надежному конституционному порядку. И, как полагает Я.Клабберс, «конституционализм формирует определенную систему отношений, эта система едина, а не просто совокупность изолированных и часто противоречивых действий» ${ }^{16}$. В этом смысле многие ученые используют глобальную конституционализацию как метод законного расширения международных режимов на глобальном уровне.

Анализ исследовательских подходов позволяет выделить три основные исследовательские парадигмы становления конституционализма на надгосударственном уровне. В основе первой лежит стремление обосновать взаимодействие на этом уровне исключительно конституций и через интересы конкретного государства. Приверженцы государственного конституционализма признают его в качестве единственного источника легитимной публичной власти. Они отрицают возможность нормативного оформления международной, транснациональной или глобальной политической власти, признавая всю юридическую силу в конституции государства. По их мнению, политическая власть вне государства - чистая политика прикрытия достижения своих интересов в рамках определенной нормативной базы.

Вторая парадигма предопределяет существование глобального конституционного порядка. Приверженцы идеи глобального конституционализма считают, что он поможет преодолеть ограничения присущие национальному конституционализму. По их мнению, национальный конституционализм должен обеспечивать становление глобального. Глобальный конституционализм в их трактовке играет особую роль в рационализации комплексной системы многоуровневой политической власти, которая охватывает все проблемы и всех людей в глобаль-

\footnotetext{
${ }^{15}$ Kumm M. The Legitimacy of International Law: A Constitutionalist Framework of Analysis. European Journal of International Law 2004. 15(5): P. 907-931.

${ }^{16}$ Klabbers $J$. Constitutionalism Lite International Organizations Law Review. 2004. 1. P.31 - 58 .
} 


\section{Политика и общество 7 (115) • 2014}

ном масштабе. И третья парадигма стремиться обосновать реальность множественности политической власти на основе принципа плюрализма.

На глобальном уровне осуществление власти нормативно и институционально сильно зависит от государства. Опираясь на национальные конституционные системы, которые развиваются на основе практики государства, для становления системы международных отношений при широкой опоре на государственных судей в интерпретации глобальных правовых норм и государственных ресурсов в целях эффективного применения глобальной правовые нормы, власти на глобальном уровне требуется серьезная государственная поддержка. Этот вид структурного взаимодействия государств в качестве основных партнеров в системе политической власти представляет собой основное качество глобального управления. Вместе с тем, национальная конституция является инструментом политики, позволяющим государствам использовать его для достижения конкретных политических целей, такие как, например, конкуренция с другими государствами за инвестиционный капитал и квалифицированную рабочую силу в мировой экономике. Поэтому логика собственного развития обуславливает стремление других государств к достижению подобных целей за счет осуществления аналогичных политических действий, включая создание подобных друг другу конституций.

Государство остается ключевыми игроком системы международных отношений, но из-за процессов глобальной интеграции его способность оставаться автономным конституционным субъектом вызывает все больше политические и правовые проблемы. Как результат, появляются мнения, что конституции государств больше не могут выступать в качестве «основной конституции» в самом строгом смысле, поскольку конституционные механизмы государства не в состоянии регулировать весь спектр проблем при осуществления власти, затрагивающих его интересы в полном объеме ${ }^{17}$. Глобализация является сложной проблемой, выступающей антагонизмом для конституции государства, которая, по сути, заставляет государства в большей степени участвовать в по-

${ }^{17}$ Gerstenberg $O$. Denationalization and the Very Idea of Democratic Constitutionalism: The Case for the European Community (2001) 14 Ratio Juris. P.298 - 325 . литических отношениях за пределами своего конституционного регулирования.

Приверженцы глобального конституционализма стремятся оправдать и обосновать навязывание космополитический порядка, основанного на коллективном исследовании общего блага, общих ценностей, или общей принятии минимального набора прав. Для Д. Хельда концепция «космополитического демократического закона» сосредоточена в основном на неспособности национальных демократий реализовать полностью идею самоуправления даже в отношении собственного населения в нашем современном взаимосвязанном мире. Только по этой причине, «национальные демократии требуют международной космополитической демократии, если они хотят быть устойчивыми и развивающимися в современных условиях» ${ }^{18}$.

Так же необходимо указать на попытки расширения идеи конституционализма за счет становления привычного политико-правового порядка на глобальном уровне. В частности, Ю. Хабермас утверждает, что за счет расширения сферы международного права и существующих институциональных режимов формируется форма глобального конституционализма. По его мнению, на основе этих процессов и будет установлен космополитический порядок. Эти процессы создают «верховенство закона, которое может нормативно формировать существующие властные отношения, независимо от их демократических истоков и прямо осуществлять политическую власть в правовых рамках» ${ }^{19}$. На международном уровне, это предполагает, что политические образования должны действовать в рамках установленных нормативных рамок и в соответствии с утвержденной процедурой. Это набор правил, обеспечивающих организационную установку с формальными руководящими принципами для политических и правовых действий в сфере международных отношений.

Конституционализм в подобном понимании выступает основой политической интеграции государств. Глобальные конституционалисты выдвигают доминантой универсальную мировую конституцию, стоящую над национальными госу-

\footnotetext{
${ }^{18}$ Held D. Democracy and the global order: from the modern state to cosmopolitan governance 17 (1995); P. 23.

${ }^{19}$ Habermas $J$. Between Naturalism and Religion (Polity Press, Cambridge, 2008) 316.
} 
дарствами, которая может быть введена в действие с помощью мирового суверена и узаконивает реализацию глобальной политической власти. В связи с этим Устав ООН называется основным конституционным документом международного сообщества (например, Б. Фассбендер ${ }^{20}$ ). Соответственно, Организация Объединенных Наций рассматривается в качестве основного института, который снабжает международное сообщество необходимыми международными органами.

С точки зрения К. Томушат, международные нормы не служат интересам государства. Вместо этого, государство выполняет функцию, определенную «международным сообществом» как выполняют свои обязательства друг перед другом «для оказания конкретных услуг в интересах своих граждан» ${ }^{21}$. Он настаивает на том, что «международное сообщество» «является действительно объектом, который может быть идентифицирован в качестве юридического актора» ${ }^{22}$. Для него, международное сообщество «не является однородной организационной единицой, а может быть определено как совокупность правил, процедур и механизмов, направленных на защиту коллективных интересов человечества, основанные на восприятии общих ценностей» ${ }^{23}$. К. Томушат при этом даже говорит о «конституции человечества», которая выступает нормативной основой на международном уровне. Результатом является мировая иерархия, которая строится на основе общих прав, в соответствии с которым «государство не более чем инструмент, неотъемлемая функция сохранения интересов своих граждан в качестве юридически выраженной позиции» ${ }^{24}$.

Представленные точки зрения свидетельствуют о том, что в то время как глобальное конституционное единство направлено на создание глобальной унитарной конституция, различные формы институализации стремятся реализовать множество

${ }^{20}$ Fassbender B. 1998b. The United Nations Charter as Constitution of the International Community." Columbia Journal of Transnational Law 36:529-619. p. 567-568

${ }^{21}$ Tomuschat C. International Law: Ensuring the Survival of Mankind on the Eve of A New Century, General Course on Public International Law, 281 Recueil des Cours 9 (1999); n.3 P. 95.

${ }^{22}$ Id. at $72-73$.

${ }^{23}$ Id. at 88 .

${ }^{24} \mathrm{Id}$., at 162 . автономных подсистем в международной политике. Это говорит о том, что глобальная конституционализация выступает как некое динамическое множество. В этом контексте крайне важно различать два аспекта становления глобального конституционализма. Один фокусируется на идеализированном различии между единством и множеством международного порядка, а другой основывается на доминировании социального над государственной формой конституционализма. При этом принцип верховенства права существует в строго национальном контексте по отношению к контролю и ограничению политической власти, включая систему сдержек и противовесов и достигается за счет разделение властей (Л. Фуллер ${ }^{25}, \Gamma . \mathrm{Xapт}^{26}$, А. Шайо). Принцип верховенства права эмпирически относится к отношениям между национальными государствами, и таким образом, следует, что международное право является нормативной основой, регулирующей межгосударственные отношения. Принципа верховенства права, встроенный в идею конституционализации, придает международному праву свой формальный характер ${ }^{27}$.

В отличие от государственных и глобальных конституционалистов, третья группа ученых - это приверженцы идеи «конституционного плюрализма». То, что началось как теория распределения конституционных полномочий в современной Европе, все чаще представляется в виде привлекательного видения глобальной политической власти. Н. Мак-Кормик первоначально описал это как идею «конституционного плюрализма», который он определил как следующим образом: «там, где есть множество институциональных нормативных положений, каждое из которых функционирует как конституция, вполне возможно, что каждое признает легитимность любой другой в пределах своей собственной сферы, в то время, как ни одно не утверждает или подтверждает конституционное превосходство над другой» ${ }^{28}$.

${ }^{25}$ Fuller L. L. 1964. The Morality of Law. New Haven, Conn.: Yale University Press. P.33 -94

${ }^{26}$ Herbert H. L.A. 1961. The Concept of Law. Oxford: Clarendon Press.

${ }^{27}$ Lauterpacht H. 1950. International Law and Human Rights. London: Stevens. P. 60-67 .

${ }^{28}$ Maccormick N. Questioning sovereignty. Oxford U. Press 1999 n.8, P. 104. 


\section{Политика и общество 7 (115) • 2014}

Н. Уокер ${ }^{29}$, как убежденным критик глобального конституционного единства, утверждает, что существует ряд отличных условий и процессов. По его мнению, конституционализм и процесс конституционализации являются неким набором свободно и разнообразно связанных факторов, что позволяют различать различные формы конституционализма и определить режимы и степень конституционализации. Н.Уокер предположил, что так же, как мы можем применить этатистские предположения конституционализма в пределах Европы, так тоже можно посмотреть конституционализм (и, следовательно, конституционный плюрализм), как относящиеся к различным сферам глобальной власти. Он согласен, что Европейский Союз находится в авангарде негосударственных образований, участвующих в представлении конституционности будущего ${ }^{30}$. С позиций плюрализма конституционное проявляется в концептуализации множественного конституционализма или метаконституционализма, который представляет идею конституционного верховенства, условия взаимодействия на горизонтальном уровне множества элементов конституционной структуры, которые формируют метаконституционный механизм, который может действовать как инструмент для межличностного совещательного решения ${ }^{31}$.

В свою очередь Н. Криш ${ }^{32}$ понимает плюрализм в качестве альтернативы попыткам конституционализации глобального политического порядка в единых нормативных рамках. Он утверждает, что узкое понимание конституционализации стремится преуменьшить возможность правового разнообразия в глобальной политии. Такое разнообразие срабатывает, с одной стороны, за счет существования разнообразных глобальных групп с определенными интересами, которые не могут претендовать на полное достижение легитимности и, с другой стороны, различных путей реализации права на участие

${ }^{29}$ Walker $N$. The Idea of Constitutional Pluralism». Modern Law Review 2002. 65(3): P. 339-340

${ }^{30}$ Walker $N$. The EU and the WTO: Constitutionalism in a New Key, in The EU and the WTO: Legal and Constitutional Issues 31,35 .

${ }^{31}$ Walker N. The Idea of Constitutional Pluralism ' ( 2002 ) 65 Modern Law Review 385.

${ }^{32}$ Krisch N. 2006. «The Pluralism of Global Administrative Law».European Journal of International Law 17(1): P. 248. в определении сферы применения государственного устройства.

В своих исследованиях Д. Хальберстам указывает на условия, необходимые для существования плюрализма: во-первых, множество частично автономных органов или учреждений государственного управления с взаимно противоречивыми претензиями на власть, а во-вторых, взаимно встроенный открытость в этих органов или учреждения в отношении претензий друг друга на власть. Это часто относится к взаимодействию между государствами в области международных отношений, в которых участвуют институты глобальной власти, а также в отношениях между различными институтами общественной власти в глобальном масштабе. Кроме того, это также верно для сосуществования нескольких систем или режимов, а также для сосуществования нескольких разнонаправленных институтов в пределах одного режима ${ }^{33}$.

Достаточно показательным примером возникновения надгосударственных конституционных систем является попытка установления единых конституционных условий в рамках Европейского союза. Одной из ключевых проблем становления конституционного порядка в Европейском союзе является противоречие между единством, целостностью самого союза и потребностью государств участников в конституционной открытости и самостоятельности во взаимоотношениях друг с другом и с внешним миром. Становление Европейского союза отразило проблематичность в развитии конституционализма на надгосударственном уровне в Европе. Тем не менее, образование Европейского союза явилось попыткой формирования значимого политико-правового проекта осуществления политической власти на надгосударственном уровне с опорой на национальные конституционные традиции. Именно поэтому Европейский союз можно считать моделью конституционного плюрализма. Действительно, плюрализм в Европе отражает то, что Дж. Вейлер назвал принципом «конституционной толерантности» ${ }^{34}$. Но динамика развития Евро-

\footnotetext{
${ }^{33}$ Halberstam D. Local, global, and plural constitutionalism: Europe meets the world. Public law and legal theory working paper series Working paper No. 176, december 2009.

34 Weiler J.H.H. Federalism without Constitutionalism: Europe's Sonderweg, in the federal vision 54, 62-70 (K. Nicolaidis \& R. Howse eds., Oxford U. Press 2001).
} 
пейского союза отражает противоречие между двумя стратегиями: стремлением к самопоглощению и формированию единого конгломерата или стремлением к конституционной открытости составляющих его государств в их взаимоотношениях друг с другом и остальным миром.

Надгосударственный конституционализм является попыткой установления преемственности основных политических концепций и отечественных традиций; он пытается избежать разрыва между развитием государств и проблемами глобализации и глобального управления. С началом процесса становления надгосударственного конституционализма, были выделены три основополагающих конституционных элемента: формальный принцип международного верховенства права, материального измерения, представляющего положения прав человека, и фактор времени позволяющий формировать глобальный конституционный порядок.

Основой конституционализма, по сути, является идея ограниченного коллективного самоуправления. Конституционализм является частной теорией политической власти, которая выросла из современной либеральной просветительской традиции. Она воплощена наиболее заметно в современном конституционном движении в форме национальных конституций как своего доминирующего выражения. Но конституционализм, как идея и теория публичной власти, шире и разнообразнее, чем его различные экземпляры, нашедшие отражение в национальных конституциях. В теории легитимности политической власти, идея конституционализма дает ответ на вопрос, почему у государства есть конституции. И, таким образом, в конечном итоге это дает точку отсчета понимания легитимности политической власти даже за пределами традиций национальной конституции. Поэтому попытки обоснования надгосударственного конституционализма опираются на легитимационный потенциал конституционализма, этот путь является довольно привлекательным, чтобы сформировать реальную систему наднационального конституционализма.

Исследования становления конституционализма как на европейском, так и на глобальном уровнях по сути своей являются попыткой концептуализации конституционализма на этих уровнях по аналогии с моделями, которые в рамках национального государства доказали успешность и привлекательность в течение длительного периода времени. Но эти попытки предполагают определенную реакцию на меняющиеся обстоятельства осуществления политической власти в постнациональных условиях, что нивелирует устоявшиеся модели конституционализма и требует новой концептуализации. Конституционализм - особенно его государственный модели - это исторически очень конкретная форма, через которую возможно реализовать основные политические ценности, личную свободу и коллективное самоуправление. Но как показывает опыт, применение внутригосударственных аналогий на международном уровне вызывает определенную скептическую оценку политиков и юристов.

Одной из ключевых проблем становления надгосударственного конституционализма является феномен суверенитета. Ее существование приводит к неурегулированной иерархии политической власти в отношениях между международными и национальными государственными институтами, а также в отношении между различными гражданскими организациями на глобальном уровне. Сам по себе статус суверенитета происходит от человечества, то есть как принцип, что права человека, интересов, потребностей и безопасности, должны уважаться и поощряться. Этот статус - основа системы международных отношений. Где человечество является основополагающим фактором в нормативном смысле, потому что государства не является самоцелью, а являются составным политическим субъектом, сущность которого заключается в выполнении общественных функций, необходимых для человека: сосуществование и безопасность. Государственный суверенитет является основополагающим принципом межгосударственных отношений только в онтологическом смысле, потому что государства должны стремиться к взаимному уважению суверенитета друг друга - при «горизонтальном» взаимодействии равноправных субъектов.

Другой, возможно, самой большой проблемой между внутренней и международной политической активностью - это проблема соблюдения демократической легитимности и не допущения скатывания к авторитарности. В рамках парадигмы становления надгосударственного конституционализма дефицит демократии должен быть принят всерьез. Глобальная конституционализация является полезной, потому что она делает актуальным вопрос о легитимности глобальной политической власти. Но применительно к глобализации политической вла- 


\section{Политика и общество 7 (115) • 2014}

сти демократия выделяет такие проблемы как несовершенство различных форм участия во внутренних и международных политических институтах, а также проблему представления интересов конкретных лиц и групп по всему миру в отсутствие глобального демоса ${ }^{35}$.

Ряд ученых указывает на то, что идея конституционализации должна стать синонимом соответствующих элементов демократизации и демократической легитимности. Без привязки процесса глобальной конституциолизации к легитимизации власти через демократическое включение, на участии правоохранительных органов или к форме республиканской этики, он открывает возможность создания иллюзии легитимности глобальной политической власти несмотря на существующее неравенства и структурные злоупотребления властью.

Становление нового демократического конституционализма может произвести компенсационный эффект. Его становление будет направлено против поглощающей динамики глобального капитализма с целью формирования единого глобального государственного устройства. Такие существенные факторы как глобальная конституция, глобальное представительное институциональное сообщество, единая политика, реализованная в глобальном масштабе, переговорная система транснационального обмена между глобальными коллективными субъектами, система ограничения политической власти в глобальных политических процессах в своей совокупности позволяет потенциально привести к становлению нового глобального конституционализма в глобальном обществе.

Потребность международной конституциализации обусловлена тем, что современные международные отношения является продуктом в высокой степени децентрализации политических процессов. В частности, международные нормы и институты часто развиваются в специализированные функциональные режимы, такие как права человека, окружающая среда, торговля или международное уголовное право. Каждая функционально дифференцированная сфера имеет свои договоры, принципы и институты. Тем не менее, ценности и ин-

${ }^{35}$ Howse R., Nicolaidis K., Democracy without Sovereignty: The Global Vocation of Political Ethics, in T. Broude and Y. Shany, eds., The shifting allocation of authority in international law 163, 178 (Hart: Oxford and Portland, 2008). тересы, определяющие какой-либо конкретный политико-правовой режим, не обязательно согласуются с другим специализированным режимом. На практике, специализированные международные отношения, их организация, разрешение споров, как правило, относительно изолированы от событий в соседних областях, рискуя породить противоречивые суждения, противоречащие праву, и результаты не в состоянии в достаточной мере учитывающие полную многомерность политико-правовой среды.

Поэтому проблема глобального конституционализма актуальна не только в сфере международной политики и международного права, но и в равной степени для других секторов глобализирующегося общества: мировой экономики, науки, техники, образования, медицины и средств массовой информации. В этих условиях в качестве ключевой возникает потребность сопряжения интересов политической власти, формирующейся в условиях глобального конституционализма и социальных подсистем для обеспечения целостности и безопасности отдельных лиц и организаций.

Глобализация расширяет перечень вероятно выгодных соглашений о сотрудничестве. В то же время, увеличение транснациональные взаимодействия может привести к тому, что глобализация установит неконтролируемые формы экономического или политического взаимодействия различных субъектов. Поэтому, задача состоит в том, чтобы процесс глобализации опирался на устойчивые политические и институциональные отношения, стремясь к достижению конституционного порядка. Диалектическая взаимосвязь между глобализацией и конституционализмом в современном обществе возникает для достижения социальных изменений обеспечивающих выгодное международное взаимодействие, в том числе по международной торговле, международной экологической безопасности, международному сотрудничеству в борьбе с организованной преступностью и т.д. В этой связи и появляется растущий спрос на международные конституционных норм и процессы, которые содействовали бы становлению конституционализма на надгосударственном уровне.

Вместе с тем, необходимо указать, что конституционализм не может быть идеальным инструментом на постнациональной пространстве. Возникнув как особенная система, он подходит для возможности «народа» управлять собой, что вызывает определенные трудности, учитывая радикальная раз- 
нообразие, которое знаменует собой глобальный население. Существующие подходы к теории надгосударственного конституционализма, чей статус не совсем определен - конституционная доктрина, социологическая теория, политический манифест или социальная утопия - не дают полной ясности. Существующие подходы говорят и об упадке конституционализма, который полное развитие получил в политической конституции национального государства. Но его основы уже размываются как европейской интеграцией и появлением транснациональных режимов, так и передачей политической власти частным коллективным субъектам. Альтернативную форму национальной конституции сейчас сложно найти в транснациональном пространстве.

Тем мне менее, можно определить три элемента, которые могут учитываться при концептуализации глобального конституционализма. Во-первых, любая конституционная система предполагает существование легальность, поэтому концепция глобального конституционализма должна включать некоторые формальные нормы, обеспечивающие легальность политической власти. Во-вторых, устойчивость политической системы должна быть гарантирована установлением ключевых идей и ценностей, которые способны обеспечить согласие общества на деятельность политической власти. И, в-третьих, основания для формирования глобального конституционализма должны быть привязаны к идее процесса, что не предполагает достижения определенных результатов (в противовес становлению конституционного строя в государстве). По своей сути, глобальный конституционализм - это не просто специфическое событие, а скорее процесс непрерывного развития.

Таким образом, в современном обществе становление надгосударственного конституционализма обусловлено, во-первых, необходимостью институционального упорядочивания процессов развития существующей системы международных отношений с целью создания условий, когда более эффективная политическая активность становится катализатором развития общества, во-вторых, потребностью ограничения действия существующих субъектов политической власти и формированием новых институтов при условии сохранения сферы автономии для государства или других субъектов, и, в-третьих, для дополнения и усиления внутренних конституционных гарантий.

\section{Библиография:}

1. Preu U. Equality of States. Its Meaning in a Constitutionalized Global Order Hertie School of Governance - working papers, No. 15, April 2008.

2. Michael A. Globalization and Peremptory Norms in International Law: fromWestphalian to Global Constitutionalism? International Politics 2004. 41(3): P. 341-353.

3. Stephen G. Constitutionalizing Inequality and the Clash of Globalizations. 59-60 International Studies Review 2002. (2): P. 47-65.

4. Schorkopf F. Walter C. Elements of Constitutionalisation: Multilevel Structures of Human Rights Protection in General International and WTO-Law. German Law Journal 2003. 4(12): P.1359-1374.

5. Cass D. Z. The Constitutionalization of the World Trade Organization. Legitimacy, Democracy, and Community in the International Trading System. Oxford: Oxford University Press. 2005.

6. Peters A. Compensatory Constitutionalism: The Function and Potential of Fundamental International Norms and Structures. Leiden Journal of International Law 2006. 19(3): P.579-610.

7. Peters A. \& Armingeon K. Introduction-Global Constitutionalism from an Interdisciplinary Perspective, 16 Ind. J. Global Legal Stud. 385 (2009)

8. Peters A. Compensatory Constitutionalism: The Function and Potential of Fundamental International Norms and Structures ( 2006 ) 19 Leiden Journal of International Law 579 .

9. De Wet E. The Emergence of International and Regional Value Systems as a Manifestation of the Emerging International Constitutional Order. “ Leiden Journal of International Law 2006. 19(3): P. 611-632.

10. Trachtman J. P. The Constitutions of the WTO. " European Journal of International Law 2006. 17(3): P.623-646.

11. Joerges Ch. nd Petersmann E.U.,eds. 2006. Constitutionalism, Multilevel Trade Governance and Social Regulation. Oxford: Hart Publishing.

12. Klabbers J., Peters A.and Ulfstein G.The Constitutionalization of International Law ( Oxford University Press, Oxford, 2009 ); Werner (n. 16).

13. Teubner G. Societal Constitutionalism: Alternatives to State-Centred Constitutional Theory? In Transnational Governance and Constitutionalism: International Studies in the Theory of Private Law, 
ed. Christian Joerges, Inger-Johanne Sand and Gunther Teubner. Oxford: Hart Publishing. 2004. P. 3-28.

14. Lauterpacht $H$. International Law and Human Rights. London: Stevens. 1950. P. 61-67

15. Kumm M. The Legitimacy of International Law: A Constitutionalist Framework of Analysis. European Journal of International Law 2004. 15(5): P. 907-931.

16. Klabbers J. Constitutionalism Lite International Organizations Law Review. 2004. 1. P.31 - 58 .

17. Gerstenberg O. Denationalization and the Very Idea of Democratic Constitutionalism: The Case for the European Community (2001) 14 Ratio Juris. P. $298-325$.

18. Held D. Democracy and the global order: from the modern state to cosmopolitan governance 17 (1995); P. 23.

19. Habermas J. Between Naturalism and Religion (Polity Press, Cambridge, 2008) 316.

20. Fassbender B. 1998b. The United Nations Charter as Constitution of the International Community." Columbia Journal of Transnational Law 36:529619. p. 567-568

21. Tomuschat C. International Law: Ensuring the Survival of Mankind on the Eve of A New Century, General Course on Public International Law, 281 Recueil des Cours 9 (1999); n.3 P. 95.

22. Id. at 72-73.

23. Id. at 88 .

24. Id., at 162 .

25. Fuller L. L. 1964. The Morality of Law. New Haven, Conn.: Yale University Press. P.33-94

26. Herbert H. L.A. 1961. The Concept of Law. Oxford: Clarendon Press.

27. Lauterpacht H. 1950. International Law and Human Rights. London: Stevens. P. 60-67 .

28. Maccormick N. Questioning sovereignty. Oxford U. Press 1999 n.8, P. 104.

29. Walker N. The Idea of Constitutional Pluralism». Modern Law Review 2002. 65(3): P. 339-340

30. Walker N. The EU and the WTO: Constitutionalism in a New Key, in The EU and the WTO: Legal and Constitutional Issues 31, 35 .

31. Walker N. The Idea of Constitutional Pluralism ' ( 2002 ) 65 Modern Law Review 385.

32. Krisch N. 2006. «The Pluralism of Global Administrative Law».European Journal of International Law 17(1): P. 248.
33. Halberstam D. Local, global, and plural constitutionalism: Europe meets the world. Public law and legal theory working paper series Working paper No. 176, december 2009.

34. Weiler J.H.H. Federalism without Constitutionalism: Europe's Sonderweg, in the federal vision 54, 62-70 (K. Nicolaidis \& R. Howse eds., Oxford U. Press 2001).

35. Howse R., Nicolaidis K., Democracy without Sovereignty: The Global Vocation of Political Ethics, in T. BROUDE AND Y. SHANY, EDS., The shifting allocation of authority in international law 163, 178 (Hart: Oxford and Portland, 2008).

36. Поярков С.Ю. Конституционализм как основа рациональной политической системы современного общества // Право и политика. - 2013. - 13. - C. 1882 - 1890. DOI: 10.7256/1811-9018.2013.13.10094.

37. Борисенков А.А. Политическая власть - политическая субстанция // NB: Проблемы общества и политики. - 2013. - 6. - С. 193 - 217. DOI: $10.7256 / 2306-0158.2013 .6 .806$. URL: http://www.e-notabene.ru/pr/article_806.html

38. Борисенков А.А. Современная российская конституция о власти // NB: Вопросы права и политики. - 2014. - 1. - C. $19-44$. DOI: 10.7256/2305-9699.2014.1.10585. URL: http:// www.e-notabene.ru/lr/article_10585.html

39. Глигич-Золотарева М.В. «Увлечение общими местами» и ценностный компонент конституционализма // NB: Проблемы общества и политики. - 2013. - 3. - C. 296 - 317. DOI: 10.7256/2306-0158.2013.3.503. URL: http:// www.e-notabene.ru/pr/article_503.html

40. Щупленков О.В., Щупленков Н.О. Проблемы взаимодействия гражданского общества и государства в современной России // NB: Вопросы права и политики. - 2013. - 4. - C. 1 - 55. DOI: 10.7256/23059699.2013.4.585. URL: http://www.enotabene.ru/lr/article_585.html

41. Знаменский Д.Ю., Михалина О.А. Влияние типа политической системы на модель формирования государственной политики // NB: Проблемы общества и политики. 2014. - 3. - C. 87 - 100. DOI: 10.7256/23060158.2014.3.11121. URL: http://www.e-notabene.ru/pr/article_11121.html 


\section{References (transliteration):}

1. Preu U. Equality of States. Its Meaning in a Constitutionalized Global Order Hertie School of Governance - working papers, No. 15, April 2008.

2. Michael A. Globalization and Peremptory Norms in International Law: fromWestphalian to Global Constitutionalism? International Politics 2004. 41(3): R. 341-353.

3. Stephen G. Constitutionalizing Inequality and the Clash of Globalizations. 59-60 International Studies Review 2002. (2): R. 47-65.

4. Schorkopf F. Walter C. Elements of Constitutionalisation: Multilevel Structures of Human Rights Protection in General International and WTO-Law. German Law Journal 2003. 4(12): R.1359-1374.

5. Cass D. Z. The Constitutionalization of the World Trade Organization. Legitimacy, Democracy, and Community in the International Trading System. Oxford: Oxford University Press. 2005.

6. Peters A. Compensatory Constitutionalism: The Function and Potential of Fundamental International Norms and Structures. Leiden Journal of International Law 2006. 19(3): R.579-610.

7. Peters A. \& Armingeon K. Introduction-Global Constitutionalism from an Interdisciplinary Perspective, 16 Ind. J. Global Legal Stud. 385 (2009)

8. Peters A. Compensatory Constitutionalism: The Function and Potential of Fundamental International Norms and Structures ( 2006 ) 19 Leiden Journal of International Law 579 .

9. De Wet E. The Emergence of International and Regional Value Systems as a Manifestation of the Emerging International Constitutional Order. “ Leiden Journal of International Law 2006. 19(3): R. 611-632.

10. Trachtman J. P. The Constitutions of the WTO. " European Journal of International Law 2006. 17(3): R.623-646.

11. Joerges Ch. nd Petersmann E.U.,eds. 2006. Constitutionalism, Multilevel Trade Governance and Social Regulation. Oxford: Hart Publishing.

12. Klabbers J., Peters A.and Ulfstein G.The Constitutionalization of International Law ( Oxford University Press, Oxford, 2009 ); Werner (n.16).

13. Teubner G. Societal Constitutionalism: Alternatives to State-Centred Constitutional Theory? In Transnational Governance and Constitutionalism: International Studies in the Theory of Private Law, ed.
Christian Joerges, Inger-Johanne Sand and Gunther Teubner. Oxford: Hart Publishing. 2004. R. 3-28.

14. Lauterpacht H. International Law and Human Rights. London: Stevens. 1950. R. 61-67

15. Kumm M. The Legitimacy of International Law: A Constitutionalist Framework of Analysis. European Journal of International Law 2004. 15(5): R. 907-931.

16. Klabbers J. Constitutionalism Lite International Organizations Law Review. 2004. 1. R.31 - 58 .

17. Gerstenberg O. Denationalization and the Very Idea of Democratic Constitutionalism: The Case for the European Community (2001) 14 Ratio Juris. R. $298-325$.

18. Held D. Democracy and the global order: from the modern state to cosmopolitan governance 17 (1995); R. 23.

19. Habermas J. Between Naturalism and Religion (Polity Press, Cambridge, 2008) 316.

20. Fassbender B. 1998b. The United Nations Charter as Constitution of the International Community." Columbia Journal of Transnational Law 36:529619. r. 567-568

21. Tomuschat C. International Law: Ensuring the Survival of Mankind on the Eve of A New Century, General Course on Public International Law, 281 Recueil des Cours 9 (1999); n.3 R. 95.

22. Fuller L. L. 1964. The Morality of Law. New Haven, Conn.: Yale University Press. R.33-94

23. Herbert H. L.A. 1961. The Concept of Law. Oxford: Clarendon Press.

24. Lauterpacht H. 1950. International Law and Human Rights. London: Stevens. P. 60-67.

25. Maccormick N. Questioning sovereignty. Oxford U. Press 1999 n.8, P. 104.

26. Walker N. The Idea of Constitutional Pluralism». Modern Law Review 2002. 65(3): P. 339-340

27. Walker N. The EU and the WTO: Constitutionalism in a New Key, in The EU and the WTO: Legal and Constitutional Issues 31, 35.

28. Walker N. The Idea of Constitutional Pluralism , ( 2002 ) 65 Modern Law Review 385.

29. Krisch N. 2006. «The Pluralism of Global Administrative Law».European Journal of International Law 17(1): P. 248.

30. Halberstam D. Local, global, and plural sonstitutionalism: Europe meets the world. Public law and legal theory working paper series Working paper No. 176, december 2009. 


\section{Политика и общество 7 (115) • 2014}

31. Weiler J.H.H. Federalism without Constitutionalism: Europe's Sonderweg, in the federal vision 54, 62-70 (K. Nicolaidis \& R. Howse eds., Oxford U. Press 2001).

32. Howse R., Nicolaidis K., Democracy without Sovereignty: The Global Vocation of Political Ethics, in T. BROUDE AND Y. SHANY, EDS., The shifting allocation of authority in international law 163, 178 (Hart: Oxford and Portland, 2008).

33. Poyarkov S.Yu. Konstitutsionalizm kak osnova ratsional'noi politicheskoi sistemy sovremennogo obshchestva // Pravo i politika. - 2013. - 13. - C. 1882 - 1890. DOI: 10.7256/18119018.2013.13.10094.

34. Borisenkov A.A. Politicheskaya vlast' - politicheskaya substantsiya // NB: Problemy obshchestva i politiki. -2013 . - 6. - C. 193 - 217. DOI: 10.7256/2306-0158.2013.6.806. URL: http:// www.e-notabene.ru/pr/article $806 . \mathrm{html}$

35. Borisenkov A.A. Sovremennaya rossiiskaya konstitutsiya o vlasti // NB: Voprosy prava i politi- ki. - 2014. - 1. - C. 19 - 44. DOI: 10.7256/23059699.2014.1.10585. URL: http://www.e-notabene. ru/lr/article_10585.html

36. Gligich-Zolotareva M.V. «Uvlechenie obshchimi mestami» i tsennostnyi komponent konstitutsionalizma // NB: Problemy obshchestva i politiki. - 2013. - 3. - C. 296 - 317. DOI: 10.7256/23060158.2013.3.503. URL: http://www.e-notabene.ru/ pr/article 503.html

37. Shchuplenkov O.V., Shchuplenkov N.O. Problemy vzaimodeistviya grazhdanskogo obshchestva i gosudarstva v sovremennoi Rossii // NB: Voprosy prava i politiki. -2013 . - 4. - C. $1-55$. DOI: 10.7256/2305-9699.2013.4.585. URL: http:// www.e-notabene.ru/lr/article 585.html

38. Znamenskii D.Yu., Mikhalina O.A. Vliyanie tipa politicheskoi sistemy na model' formirovaniya gosudarstvennoi politiki // NB: Problemy obshchestva i politiki. - 2014. - 3. - C. $87-100$. DOI: 10.7256/2306-0158.2014.3.11121. URL: http://www.e-notabene.ru/pr/article_11121.html 